Review

\title{
Food Processing: The Influence of the Maillard Reaction on Immunogenicity and Allergenicity of Food Proteins
}

\author{
Malgorzata Teodorowicz ${ }^{1,2, *}$, Joost van Neerven ${ }^{1,3}$ and Huub Savelkoul ${ }^{1,2}$ \\ 1 Cell Biology and Immunology Group, Wageningen University \& Research, 6708 WD Wageningen, \\ The Netherlands; joost.vanneerven@frieslandcampina.com (J.v.N.); huub.savelkoul@wur.nl (H.S.) \\ 2 Allergy Consortium Wageningen, Wageningen University \& Research, 6708 WD Wageningen, \\ The Netherlands \\ 3 FrieslandCampina, 3818 LE Amersfoort, The Netherlands \\ * Correspondence: gosia.teodorowicz@wur.nl; Tel.: +31-317-482-649
}

Received: 4 July 2017; Accepted: 1 August 2017; Published: 4 August 2017

\begin{abstract}
The majority of foods that are consumed in our developed society have been processed. Processing promotes a non-enzymatic reaction between proteins and sugars, the Maillard reaction (MR). Maillard reaction products (MRPs) contribute to the taste, smell and color of many food products, and thus influence consumers' choices. However, in recent years, MRPs have been linked to the increasing prevalence of diet- and inflammation-related non-communicable diseases including food allergy. Although during the last years a better understanding of immunogenicity of MRPs has been achieved, still only little is known about the structural/chemical characteristics predisposing MRPs to interact with antigen presenting cells (APCs). This report provides a comprehensive review of recent studies on the influence of the Maillard reaction on the immunogenicity and allergenicity of food proteins.
\end{abstract}

Keywords: Maillard reaction; advanced glycation end products (AGEs); Maillard reaction products (MRPs); immunogenicity of AGEs; allergenicity of AGEs; Maillard reaction in food

\section{Food Processing}

Most of the food consumed nowadays by developed societies is processed. The diversity of processed food products increased exponentially during the last century, along with the need for more safe, convenient and varied food products. Methods used for food processing can be categorized into two processing types: conventional thermal methods, including pasteurization, sterilization, drying and roasting $[4,5]$ and non-thermal, novel methods such as high pressure treatment [6], electric field treatment [7,8], irradiation [9] or applications of cold plasma [10]. Foods are subjected to thermal processing mainly to preserve them by inactivating microbes (high temperature treatment), to improve their sensory qualities (e.g., flavor, texture, taste, and smell) or to obtain another food product or ingredient from a food source (e.g., protein isolates, cheese, oils). From a biochemical perspective, thermal processing promotes chemical and physical changes of food proteins, and affects protein conformation - and therefore also immunogenicity and allergenicity-by promoting interactions of food proteins with other components present in the food matrix.

\section{Thermal Processing Induces Conformational Changes in Food Proteins}

Native proteins are folded into specific and compact 3D structures. This is determined by primary structure (sequence of amino acids), secondary structure (formation of $\alpha$-helixes and $\beta$-sheets) and tertiary structure. The formation of $\alpha$-helixes and $\beta$-sheets is driven by interactions 
between polypeptide chains linked together by hydrophobic and hydrophilic interactions, electrostatic interactions and disulfide bonds [11]. All these chemical interactions create a unique protein conformation that is reorganized at all structural levels during heat treatment. Changes in $\alpha$-helix and $\beta$-sheet structures start to occur at heating temperatures above $55^{\circ} \mathrm{C}$, and almost complete loss of secondary and tertiary structure as well as cleavage of disulfide bonds occurs at temperatures above $70-80^{\circ} \mathrm{C}[12,13]$. At the same time, because of protein denaturation, irreversible intermolecular interactions may result in protein aggregation and cross-linking reactions between amino acids, e.g., through formation of lysinoalanine (LAL) [14]. These heat-induced conformational changes of food proteins may further affect digestion and absorption of proteins/peptides by the intestinal epithelium, as well as their recognition by immune cells. Moreover, if sugars are present during the heat treatment, the free amino groups of side chains of amino acids can be blocked due to the Maillard reaction $[11,13]$.

\section{The Maillard Reaction in Food Processing}

One of the best-known interactions between proteins and sugars occurring during heat processing of food is the Maillard reaction (MR), also known as glycation. During the MR, sugars are linked to proteins by a covalent bond between free amino groups of amino acids (mostly lysine and arginine) and the carbonyl groups of a reducing sugar (simplified scheme on Figure 1).

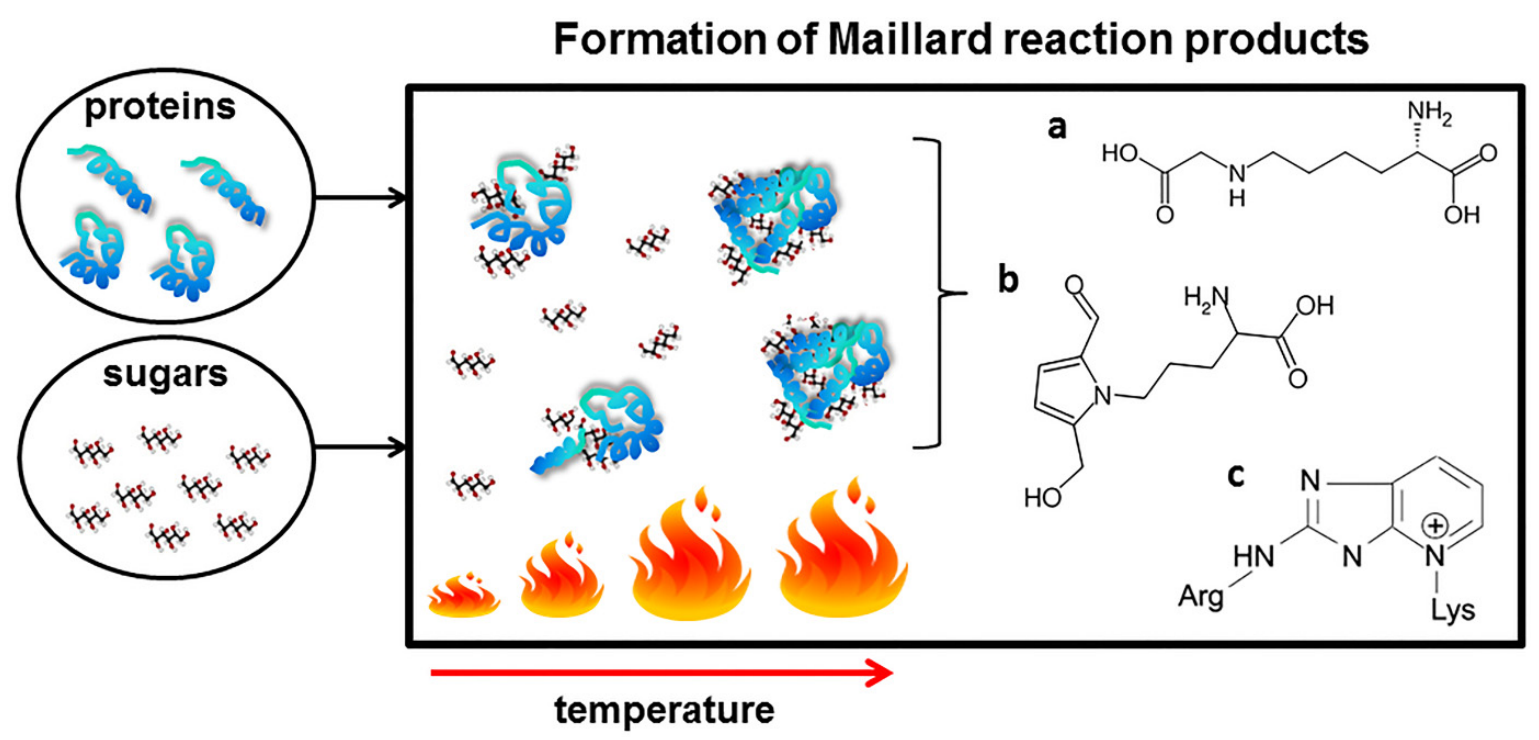

Figure 1. Simplified scheme of the formation of Maillard reaction product during food processing. Amadori rearrangement leads to the formation of a number of advanced glycation end products, among others: (a) Ne-(carboxymethyl)lysine; (b) pyrraline and (c) pentosidine.

The MR occurs naturally during regular food processing and meal preparation (cooking, frying, and baking) [15-17]. However, the chemistry of the reaction is extremely complex. A cascade of chemical rearrangements including condensation, oxidation and hydration, leads to formation of numerous Maillard reaction products (MRPs). The Schiff bases formed as the first products of the reaction are followed by their Amadori rearrangement and subsequent oxidative modifications (glycoxidations) resulting in the formation of advanced glycation end products (AGEs). The chemical nature of many of the AGEs is unknown due to their heterogeneous and unstable nature. However, a growing number of structurally defined AGEs such as pyrraline, pentosidine and $\mathrm{N} \varepsilon$-carboxymethyllysine (CML) have been found in processed food $[18,19]$.

Moreover, the type and amounts of MRPs formed are under the control of factors such as the structural diversity of (poly)saccharides and proteins, reaction temperature and time, ratio of amino 
group and reducing sugar, $\mathrm{pH}$ and water activity $[15,20]$. MRPs are known to confer functional characteristics to food proteins such as appearance, smell, taste and texture. For this reason, the MR is a relevant reaction for consumers therefore also for the food industry $[17,21]$. In addition to functional changes of proteins, many studies in the last decade have revealed that the MR also affects biological properties of food proteins such as their digestibility, bioavailability, immunogenicity and consequently their allergenicity. Biochemical and conformational changes of proteins caused by MR may result in masking of existing antibody binding epitopes, but also in creating new structures that are more immunogenic and are thus able to promote the initiation of IgE-mediated allergies [22-25].

\section{Influence of Maillard Reaction of Digestibility of Proteins}

In order to elicit an allergic immune response, food proteins (or peptides thereof) must survive digestion and remain in the gastrointestinal tract for a period of time that is sufficient to induce sensitization. From that perspective, the susceptibility of food proteins to enzymatic hydrolysis seems to be an important factor determining their allergenicity [26-28]. Even so, not all food allergens are resistant to digestion $[29,30]$. As described above, both heating and the MR can alter the susceptibility of proteins to gastrointestinal digestion due to unfolding, heat-induced disulfide bond interchanges, aggregation, the formation of lactulosyllysine, and formation of AGEs, thereby affecting the availability of enzymatic cleavage sites on the protein backbone.

Heating itself causes unfolding of protein and exposure of linear epitopes and may result in enhanced susceptibility to enzymatic proteolysis as described for $\beta$-lactoglobulin heated at the temperature of $90^{\circ} \mathrm{C}$ [31]. However, Corzo-Martínez and colleagues demonstrated that denaturation and aggregation of heated $\beta$-lactoglobulin caused by MR led to decreased $\beta$-LG proteolysis [32]. A band corresponding to intact $\beta$-LG was observed on SDS-PAGE picture after trypsin/chymotrypsin digestion of $\beta$-LG glycated with galactose and tagatose at $40{ }^{\circ} \mathrm{C}$ for one day, even after $1 \mathrm{~h}$ of digestion. Resistance to gastrointestinal digestion was more evident in $\beta$-LG glycated with galactose than tagatose which was shown previously to be a less efficient sugar in formation of MRPs [33]. Therefore, the results of that study revealed that higher degrees of glycation of bovine $\beta$-LG lead to a higher resistance to proteolysis. This could be explained by lower susceptibility of glycated lysine and arginine residues to trypsin/chymotrypsin proteolysis by masking the sites of cleavage [18]. In addition, Maillard reaction-induced protein aggregates may protect proteins during in vitro gastrointestinal digestion, which was shown by inhibition of aggregation of $\beta$-LG in the presence of pyridoxamine [32], an effective inhibitor of formation of MRPs on all stages [34]. Those results are in line with a number of other studies that demonstrated impaired enzymatic hydrolysis in vitro due to the MR observed together with decreased protein solubility caused by denaturation, structural rearrangements and aggregation of proteins heated with sugar [25,35-37]. In contrast, glycation has also been reported to increase protein solubility [38,39] as well as protein digestibility as it has been shown for lysozyme [40] and codfish parvalbumin [41], suggesting that an effect of MR on protein digestibility may be connected with structural characteristic of the protein that is studied. Moreover, the diversity of conditions used for glycation in the different experiments as $\mathrm{pH}$, time of heating, temperature of heating, ionic strength of the medium, water activity and type of sugar may also explain the disparity often observed in the literature on the influence of MR on protein digestibility. Liu and colleagues showed that the glycation of whey proteins at different conditions of water activity and $\mathrm{pH}$ alternates the peptide profiles observed on HPLC chromatograms [42]. The local environment of lysine changes in differently unfolded proteins at $\mathrm{pH} 5,7$ or 9, which affected the susceptibility for glycation, the type of formed MRPs (e.g., formation of agglomerates), and subsequently modified the protease action, resulting in a different peptide composition after enzymatic hydrolysis [42].

The number of studies involving in vivo experiments investigating an effect of MR on digestibility of food proteins is limited to date. A recently published study performed on humans compared the effects of diets with different MRP contents on dietary protein utilization in adolescent males. The study revealed that a diet high in the MRPs limits the digestibility of proteins since $47 \%$ higher 
fecal nitrogen excretion, $12 \%$ lower apparent nitrogen absorption and $6 \%$ lower nitrogen digestibility was observed in the group consuming diet high in MRPs [43]. Hellwig and colleagues [44] have shown that the human colonic microbiota are able to degrade the following MRPs: Ne-fructosyllysine, $\mathrm{CML}$ and pyrraline. This suggests that the released glycated peptides and amino acids may be used by microbes as the source of energy or can be transported via intestinal barrier as it was proposed for small pyrraline peptides [45]. This shows the relevance of microbiota in the degradation process of Maillard reaction-modified proteins and therefore also their absorption in the intestine.

\section{Absorption of MRPs in Intestine}

The question if the glycated protein/peptide can have immunological effect in vivo depends on whether these molecules are available in the gastrointestinal mucosa to be absorbed into the circulation and subsequently to get in contact with the immune system. Dietary MPRs were shown to appear in the circulation and/or urine of human subjects after consumption of MRPs rich diet [18,46-52]. The study performed by Hellwig and colleagues on glycated casein samples revealed that fructoselysine and (CML) are released after digestion bound to peptides smaller than $1000 \mathrm{Da}$, which makes them available for absorption [52]. This was confirmed in the studies performed in the rat model showing that advanced MRP such as CML, pyrraline and pentosidine may be absorbed by the gut. Ingested dietary CML in rats appeared to be approximately $26.0-29.0 \%$ excreted in the urine, and $15.0-22.0 \%$ excreted in feces $[14,53]$. Approximately $1.7 \%$ of dietary CML accumulated in the circulation, kidney and liver and approximately $50.0 \%$ of the ingested CML was not recovered. This was later confirmed in a human study where $31.2 \%$ of ingested dietary CML was excreted in the feces, $14.4 \%$ in the urine, and $54.4 \%$ left unrecovered [48]. More than $60 \%$ of dietary pyrraline and approximately $2.0 \%$ of dietary pentosidine were excreted in urine in humans [49,50]. Different percentage of recovery of total diet amount of AGEs found in urine suggest different resorption and metabolic pathways of individual Maillard products [50]. In addition, LAL, a compound formed by cross-linking of protein, was found in the urine, plasma, liver and kidneys of rats fed with the diet with low and high LAL-content [14] although it has been reported to be released during digestion process into larger peptides of at least 30-40 amino acids [52].

Cross-linking of proteins seems to reduce an epithelial uptake of proteins although promote an uptake through Peyer's patches as was shown for crossed-linked $\beta$-lactoglobulin and $\alpha$-lactalbumin $[54,55]$. In addition, the larger agglomerates, as well as other MRPs can be further metabolised by intestinal microbes $[44,56,57]$ resulting in formation of new bioactive compounds but also modulating the intestinal microbiota composition in humans $[58,59]$. The fact that the dietary protein-bond AGEs, such as CML, pentosidine and pyrraline, are available in the gastrointestinal tract and circulation means that they can also interact with the immune cells.

\section{Influence of Maillard Reaction on Immunogenicity of Proteins}

\subsection{MR-Modified Proteins and Allergic Sensitization}

Even though the role of AGEs in chronic inflammatory diseases is more well-known and studied [47,60,61], evidence is emerging that AGEs also play a role in allergy. As this paper focuses on allergy, the role of AGEs in chronic inflammation will not be discussed in details.

Allergy is commonly divided in two phases. An initial phase of allergic sensitization represents principally a particular immune reaction leading to the formation of allergen-specific IgE antibodies. IgE antibodies can crosslink adjacent cell-bound IgE molecules on basophils and mast cells upon repeated exposure to allergens, leading to degranulation and the release of mediators, including histamine, prostaglandins, leukotriens and tromboxanes. These mediators cause the typical symptoms of a type 1 (within $20 \mathrm{~min}$ ) IgE-mediated allergy, including rhinitis, atopic dermatitis, allergic asthma, and occasionally even anaphylaxis [62]. 
Immunogenicity of proteins is thus dependent on their ability to eventually induce adaptive T-and B-lymphocyte responses during the allergic sensitization phase (see Figure 2). This is strongly influenced by the efficiency of antigen uptake and processing, as well as by the activation status and production of cytokines by myeloid antigen presenting cells (APC: monocytes, macrophages, and dendritic cells). Receptor-mediated endocytosis—as opposed to pinocytosis—is an efficient way of antigen uptake that facilitates adaptive immune responses at low antigen exposure and also induces activation and cytokine production by antigen presenting cells. APCs such as dendritic cells (DC) can use Fc receptors [63], RAGE (receptor for advanced glycation end products) [64,65], dectin-1, 2 and 3 [66,67], DC-SIGN [68], galectin-3 [69] and mannose receptors [70] for efficient antigen uptake. For example, it is known that IgG-immune complexes are more immunogenic because they are targeted to CD32/Fc 8 RII receptors on APCs [71]. This was also shown for an uptake of allergen-IgE complexes via CD23/FceRII, resulting in efficient $T$ cell activation at 100-fold lower antigen concentrations [72]. These findings suggest that interaction with specific receptors on APC may be of importance to understand an immunogenic character of dietary AGEs (see Figure 2).

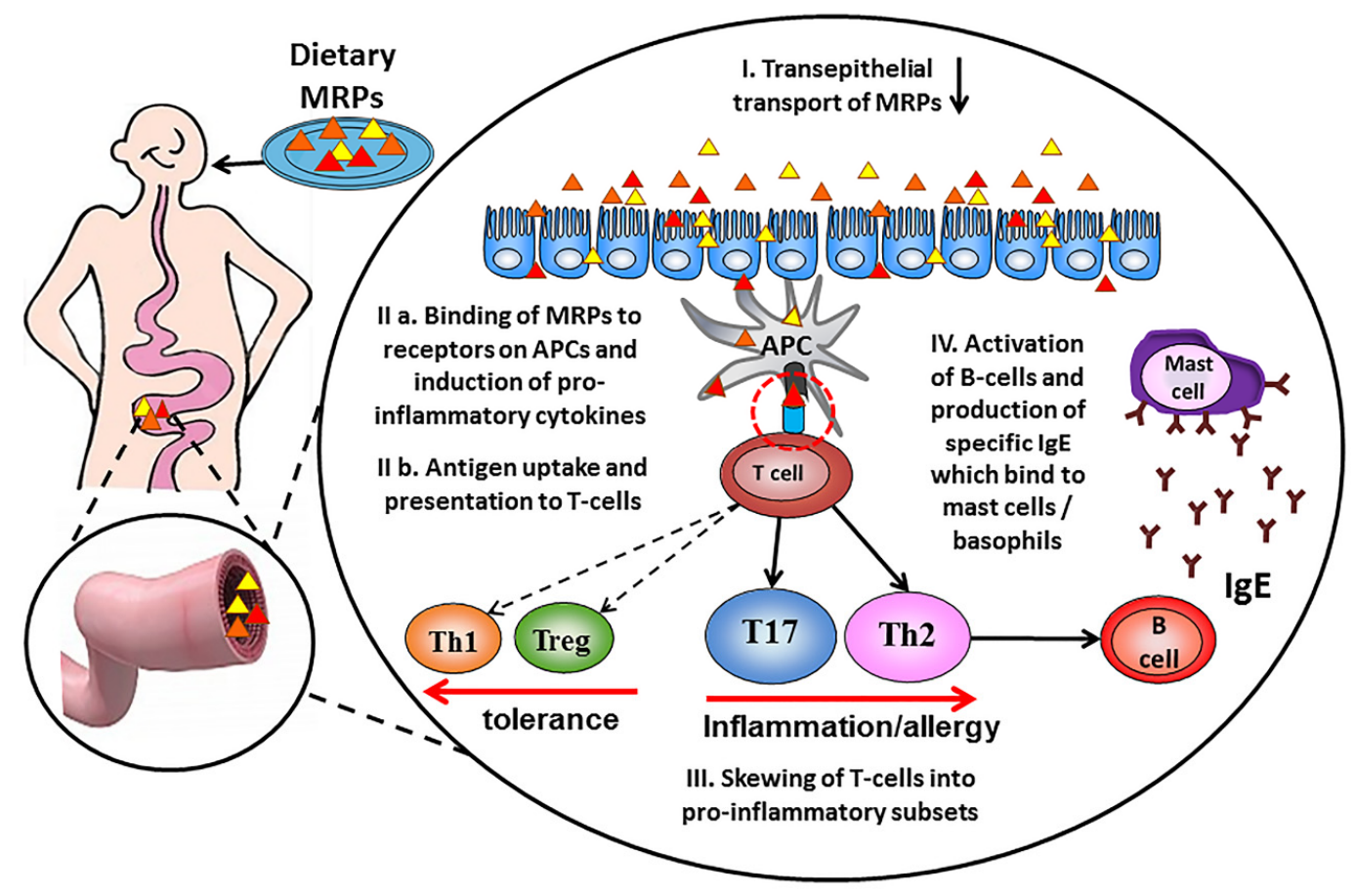

Figure 2. Schematic contribution of dietary Advanced glycation end products in the allergic sensitization process. Dietary Maillard reaction products (MRP) are taken up in the gut by crossing the epithelial barrier (I), leading to antigen uptake by mucosal dendritic cells and presentation of peptides to specific T-cells (II). Activated antigen-specific helper Th cells differentiate into pro-inflammatory and allergy-inducing Th17 and Th2 subsets (III). Allergen-specific B-cells become activated upon ligand binding and start the production of allergen-specific IgE antibodies (IV) that bind to mast cells and basophils and become detectable in the circulation.

\subsection{Interaction of MR-Modified Proteins with Receptors Present on APCs}

To induce an allergic immune response the MR-modified protein need to be recognized and taken up by antigen presenting cells (APCs) and subsequently presented to T-cells [24]. Recently more evidence has been found that some MRPs may function as activators of dendritic cells (DCs) via targeting AGE receptors [23,73-75]. Several receptors mediating antigen uptake, activation and maturation in DCs were identified as potential receptors for dietary MRPs, including AGE-receptor complex (AGE-R1/OST-48, AGE-R2/80K-H, AGE-R3/galectin-3) [76-78], members of the scavenger 
receptor family A (SR-A) and B (SR-B) [23,24,75,79-81] as well as mannose receptor [82-84]. Dry roasted Ara h1 was bound to the scavenger receptor, CD36 and the receptor for advanced glycation end products (RAGE) [24,85].

RAGE is the most studied receptor that can recognize and bind dietary AGEs [24,42,85-88]. Cellular signaling due to AGE-RAGE interactions seem to be a key component in pro-oxidative and pro-inflammatory condition [89] and this may be involved in enhanced allergic sensitization [85]. Soluble RAGE (sRAGE), the extracellular ligand-binding domains of RAGE present in the circulation, competes with membrane RAGE in binding AGEs acting as a decoy domain receptor [90,91]. Binding of AGEs to sRAGE, in contrast to interactions with membrane form of RAGE, does not result in inflammatory signal transduction therefore sRAGE acts as inhibitor of RAGE-AGE signaling and is potentially applicable for the treatment of various AGE-related diseases including diabetic cardiovascular complications [92,93], diabetic kidney disease [94] and a number of aging-related diseases including atherosclerosis, cataracts, Alzheimer's disease and Parkinson's disease $[95,96]$.

The recent study of Liu and colleagues revealed that whey proteins glycated by dry heating (at $130^{\circ} \mathrm{C}$ ) interacts with sRAGE. The strength of binding was positively correlated with the time of heating and the formation of agglomerates and was more prominent in the samples with lower water activity [86]. These findings are in line with other studies showing binding of AGE-modified peanut allergens to recombinant form of RAGE [24]. The study performed by Zill and colleagues [85,97] revealed RAGE-mediated activation of both Caco-2 cells and RAGE-transfected HEK-293 cells by chemically defined food-derived products, both, AGEs and non-AGEs. This suggests that diet-derived AGEs may activate the antigen presenting cells via RAGE. The study performed by Hou and colleagues suggest a positive correlation between the level of AGEs accumulated in the circulation of patients with chronic kidney disease and the expression of RAGE on monocytes isolated from these patients [98]. The enhanced expression of RAGE was strongly correlated with plasma levels of pentosidine, plasma levels of tumor necrosis factor alpha (TNF- $\alpha$ ), monocyte activation markers, and the systemic acute phase reactant, C-reactive protein [98]. Hilmenyuk and colleagues demonstrated activation of RAGE on immature DC via interaction with AGE-modified ovalbumin (OVA). Increased expression of RAGE on immature DCs exposed to AGE-modified OVA was seen as well as enhanced activation of the transcription factor NF- $\mathrm{kB}$ compared to DCs exposed to non-modified OVA [83]. The ligation of RAGE by CML was shown to upregulate the RAGE expression in human neuroblastoma cell line SH-SY5Y [87] as well as enhance the expression of vascular cell adhesion molecule-1 (VCAM-1) on endothelial cells [99]. These data suggest that AGE-RAGE interaction may result in NF- $\mathrm{kB}$ activation as well as upregulation of RAGE expression on immune cells what in consequence may result in secretion of pro-inflammatory cytokines and thus activation of APCs. In opposite to these results other studies show that CML-modified proteins [100] as well as Maillard-reaction modified $\beta$-lactoglobulin [101] and coffee [102] are not able to stimulate inflammatory signaling pathways in RAGE-expressing human cell lines $[100,101]$. Interestingly, ovalbumin modified by pyrraline, the other AGE, was also not shown to interact with RAGE [23]. Thus, the discussion on the ligation of RAGE with food-derived AGEs and its physiological consequences remains open and more data on activation of RAGE by AGEs are needed to prove the role of RAGE in the activation of APCs during the allergic sensitization process.

\subsection{Influence of MR-Modified Proteins on T-Cell Activation and Polarization}

Interaction of AGEs with receptors present on APCs may result in internalization and therefore presentation of antigen to T-cells. Ilchman and colleagues demonstrated that AGE-modified OVA was taken up much more efficiently by bone marrow-derived murine myeloid dendritic cells (mDCs) than native OVA, and enhanced activation of OVA-specific CD4+ T cells [75]. Scavenger receptor class A type I and II (SR-AI/II) were identified as receptors mediating the uptake of AGE-OVA [75]. These results are in line with a study using human DCs as a model for an uptake of FITC-labeled AGE-modified OVA. Enhanced uptake of AGE-modified OVA was mediated by mannose receptor, scavenger receptor and macropinocytosis. Co-culturing of CD4+ T cells with AGE-OVA-loaded mature 
DCs induced greater Th2 cytokine production (IL-5, IL-4, and IL-6), while OVA-loaded DCs induced a significant Th1 or regulatory cytokine profile [83]. The study of Moghaddam and colleagues performed on dry roasted peanut proteins confirm the ability of dietary AGEs to target antigen presenting cells via RAGE and CD36. Moreover, mice sensitized with dry-roasted peanut extract showed higher IL-4, IL-5 and IL-13 secretion by mesenteric lymph node cells showing skewing of T cell response into Th2 when compared with mice sensitized with non-treated peanut extract. High reactivity of mice primed with dry roasted peanut to raw peanut antigens suggest that roasting enhances immunogenicity of peanut extract having an important impact on the priming step of sensitization [24].

Heilmann and colleagues aimed to identify glycation structures enhancing T-cell immunogenicity of a food allergen by modification of OVA with different AGEs such as CML, CEL and pyrraline. To assess the T-cell immunogenicity of glycated OVAs, murine OVA-specific CD4+ T-cells were co-cultured with bone marrow-derived DCs in the presence of differently processed OVA samples. Pyrraline modified OVA enhanced CD4+ T-cell immunogenicity, as evidenced by increased IL-2 production, higher production of IFN- $\gamma$ and IL-17A when compared with native OVA. Moreover, pyrraline-OVA and AGE-OVA were efficiently taken up by BMDCs via SR-A. In addition to antigen uptake, cell maturation is required for DCs to gain their full T-cell stimulatory capacity. However, no differences in expression of co-stimulatory molecules CD40, CD80, CD86, and MHC class II on the cell surface of DC were seen suggesting that pyrraline modification does not induce BMDC maturation. This is in line with observations of Moghaddam and colleagues [24], who suggested enhanced targeting and presentation via AGE receptors rather than conventional DC maturation may be implicated in the increased immunogenicity of DR peanut antigens in vivo. However, this is in contrast with the work of Buttari and colleagues who showed that AGEs of plasma $\beta 2$ glycoprotein I ( $\beta 2$ GPI) triggered the maturation of monocyte-derived human DCs and polarized allogenic naive CD4+ T-cells into Th2 cells in a co-culture with matured DCs [73]. These different observations could be explained by heterogeneity of the structures MRPs and the expression profiles of receptors in these human and murine DCs.

\subsection{Role of Agglomeration in Immunogenicity of MR-Modified Proteins}

These results raise the question which structural changes triggered by MRPs can explain the immunogenicity of AGEs and capabilities to initiate the polarization of allogenic naive CD4+ T-cells into Th2 cells. Maillard reaction caused agglomeration of proteins was excluded as a major contributor to increased immunogenicity of proteins in the studies of Moghaddam and colleagues [24] and Heilmann and colleagues [23] since the samples underwent multiple rounds of filtration and centrifugation that depleted cross-linked species. However, the agglomeration of MR-modified proteins and level of cross-linking were not measured in these studies. Moreover, food processing of proteins promotes the formation of $\beta$-sheet-rich, fibrillar structures [103] known to possess high affinity binding to RAGE [104] and CD36 [105]. Pasteurization caused aggregation of beta-lactoglobulin and alpha-lactalbumin enhanced uptake of cross-linked proteins via Peyer's patches, which promoted significantly higher Th2-associated antibody and cytokine production in mice than their native counterparts $[54,55]$. These results suggest that not only Maillard reaction but also protein cross-linking can enhance immunogenicity of proteins and their sensitizing capacity.

The research outcomes discussed above provide strong evidence that some dietary AGEs can bind to receptors on antigen presenting cells and thus modify T-cell immunogenicity (the schematic contribution of dietary AGEs in the allergic sensitization process is presented on Figure 2). However, information about selectivity of AGEs structures binding to AGEs receptors is very limited. The heterogeneity of AGEs and the diversity of their receptors indicate that more study is required to elucidate the precise receptors and pathways implicated in enhanced DC-mediated uptake and presentation of antigens to $\mathrm{T}$ cells. 
6.5. Influence of MR-Modified Proteins on B-Cells Switching and the Production of Antigen Specific IgG and $\operatorname{Ig} E$

When membrane-bound immunoglobulin (Ig) of naïve B cells come in contact with specific dietary antigens, and are activated by ligation of the surface molecule CD40 to CD40L on activated Th2 cells that produce IL-4 and IL-13, the B cells are induced to switch to produce IgE. Naïve $\mathrm{B}$ cells further differentiate and proliferate into activated plasma cells synthesizing and secreting antigen-specific IgE (see Box 2). Lymphocytes activated in the GALT leave through the draining lymphatics and reach the MLN, where they stay for a period for further differentiation, before migration into the bloodstream $[62,106]$. Moghaddam and colleagues demonstrated that BALB/c mice primed subcutaneously with soluble fractions of peanut protein extract from raw or dry roasted (DR) peanuts show enhanced peanut-specific IgG titers in DR-primed groups. These results were confirmed in intra-gastric gavages of DR and raw peanut extracts showing 100-fold higher IgG titers, enhanced titers of anti-peanut IgE as well as functional basophil degranulation in DR group. Moreover, mesenteric lymph node cells from DR but not raw peanut protein-primed mice proliferated robustly in response to raw and DR peanut extract with the dominance of IL- 4 and IL- 5 over IFN- $\gamma$ and TNF- $\alpha$. The authors suggested that the observed increased immunogenicity of DR peanut antigens can be explained by selective targeting, activation and presentation of antigen via binding to AGE receptors on DCs [24].

\section{Influence of Maillard Reaction on Recognition of Food Allergens by Specific IgE}

MR induced during food processing may also modulate binding potential of specific IgE to food allergens. This can be induced by: (a) disruption of the conformational and linear epitopes accompanied with the changes of the tertiary and secondary structure that impair the IgE binding potential of the protein [12,106,107]; (b) formation of agglomerates carrying high number of epitopes that cause enhanced degranulation capacity of basophils [108]; or (c) formation of new epitopes due to aggregation and/or Maillard reaction [24] (Figure 3). These new epitopes called neo-allergens are able to target APCs resulting in antigen presentation and subsequently modulating T-cell differentiation as well as a production of antigen-specific IgE. Production of specific IgE is therefore a consequence of sensitization phase by interaction of immunogenic MRPs with APCs (see Boxes 1 and 2). Moghaddam and colleagues observed that enhanced anti-raw peanut IgE titers in mice sensitized with dried peanut extract versus those sensitized with raw peanut extract was also reflected in enhanced degranulation of basophils [24].

The MR was shown to either reduce or enhance IgG and/or IgE binding capacities of some food allergens [25,109-113]. For instance, the proteins that belong to pathogenesis-related (PR) protein family and being the homologous to birch pollen allergen Bet $\mathrm{v} 1$ show reduced IgE binding capacity after processing with sugar as it was shown for Pru av 1 [109] and Cor a 1 [114]. This can be explained by a masking effect of carbohydrates reducing an accessibility of epitopes for IgE binding (Figure 3). In contrast to (PR) protein family MR was shown to enhance IgE binding capacity to peanut proteins and scallop tropomyosin [115-117]. Thus, the influence of MR on IgE binding seems to depend on physicochemical properties of proteins (hydrophobicity, size, amino acid composition, charge) as well as on conditions of MR (type of sugar, time, water activity, $\mathrm{pH}$, temperature, presence of salts) $[118,119]$.

The study of Vissers and colleagues showed reduced allergenicity of MR-modified peanut allergen Ara $\mathrm{h} 1$ in IgE binding test while enhanced $\beta$-hexosaminidase release from basophils upon incubation with the same MR-modified allergen [113]. The authors suggest that MR-induced agglomeration of Ara h 1 may be responsible for the observed increased capacity of antigen to cross-link the IgE and initiate the mediator release from RBL-2H3 cells (see Box 1). That indicates a need to include the functional assays, next to the IgE binding tests, in the studies on allergenicity of MRPs to be able to link the results to development of acute complaints of a clinically observable allergic response (see Box 3). Based on the functional basophil activation test (BAT) Cucu et al. showed that two out of six hazelnut allergic patients showed enhanced basophil activation after exposition to MR-modified hazelnut extract [114]. Other study revealed that $70 \%$ of the patients (out of 15) sensitized to soy showed enhanced basophil 
activation in BAT assay upon incubation of basophils with MR-modified soy proteins when compared with soy proteins modified only by heating (without sugars) [22]. Moreover study of Vojdani and colleagues revealed increased levels (3-8-fold) of specific IgE against processed food antigens in 31\% of the patients when compared to raw food antigens [120]. These results suggest that some of the patients are sensitized against processed food rather than raw and the MR may play a crucial role in the enhancing of immunogenic potential of food allergens as it was already showed by Moghaddam and colleagues [24]. Therefore, the diagnosis of food allergy could be improved by incorporation of processed and MR-modified food allergens next to the raw ones into the diagnostic tests.

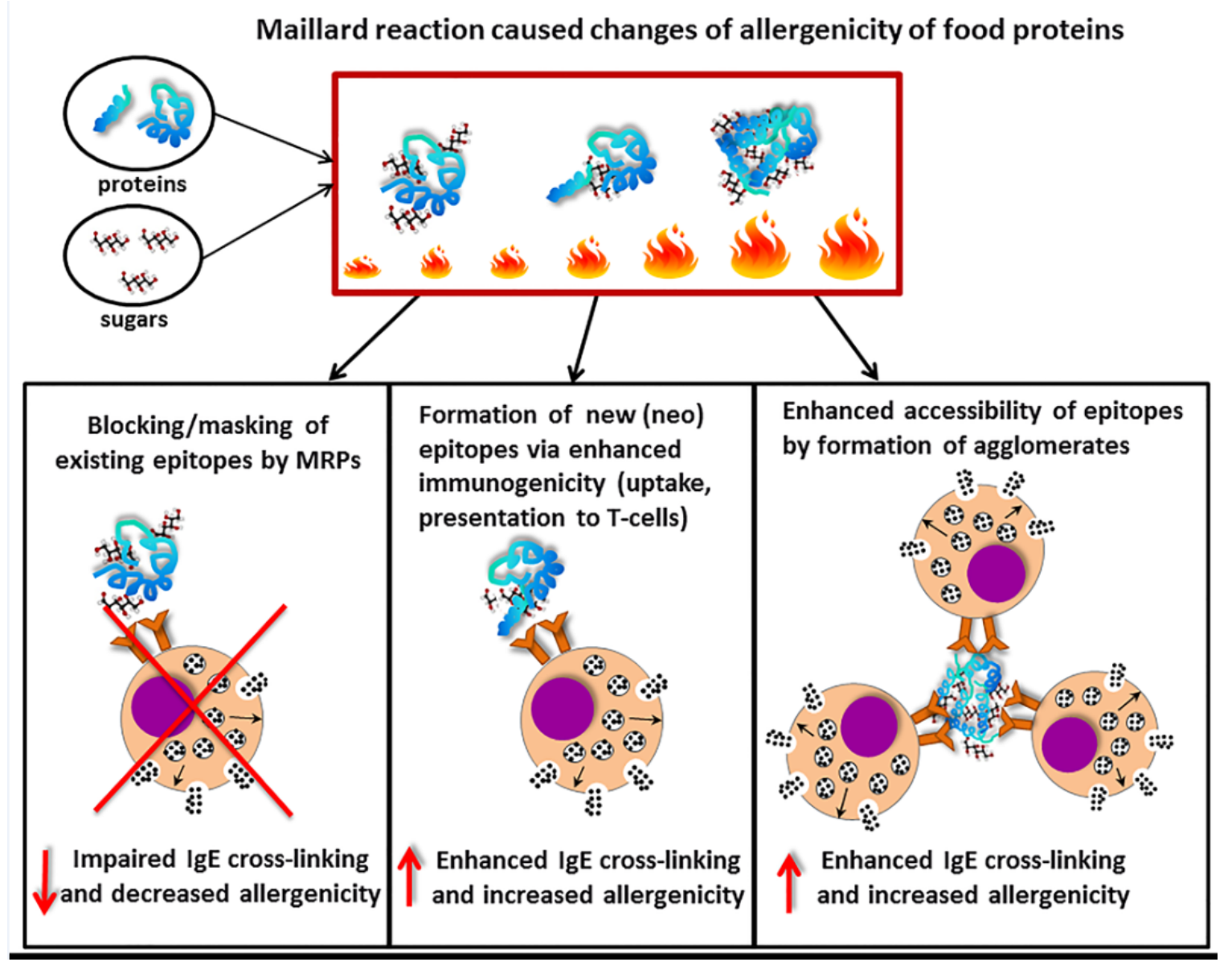

Figure 3. Modulation of allergenicity of food proteins by the Maillard reaction. Upon food processing using heating, reducing sugars will react with primary amino groups on amino acids from allergen proteins to result in Maillard reaction products (MRP). Consequently, these MRP may block epitopes thereby preventing IgE binding and crosslinking, and subsequent mediator release. This results in reduced allergenicity of the altered food allergens. Alternatively, MRP may lead to the exposure of neo-epitopes leading to enhanced uptake by antigen-presenting cells and exposure to specific T-cells and this enhanced possibility for IgE cross-linking may lead to enhanced allergenicity. Lastly, MRP may lead to the formation of agglomerates of allergen molecules resulting into enhanced IgE cross-linking and increased allergenicity. The ratio between these several possibilities determines the final outcome of the mediator release capacity of the MRP altered food allergens. 
Box 1. Immunochemical properties of allergens.

\begin{abstract}
Allergens are generally proteins that, when exposing genetically susceptible individuals frequently and in low doses $(<1 \mu \mathrm{g})$ on a mucosal surface are able to induce a Th2 response associated with the production of IL-4, IL-5, and IL-13 leading to the synthesis of allergen-specific IgE antibodies.

At present, no identified antibody characteristics and no identified structural features of IgE binding epitopes seem to be associated with the phenotype of the food allergic disease. Potential allergens must necessarily contain B-cell epitopes to which IgE can bind, and T-cell epitopes capable of inducing a Th2 type response. Peptide sequences of T-cell epitopes (10-15 amino acid residues long) show no general homology across allergen families and thus it has been proven impossible to identify a consensus sequence for an allergenic epitope [121].

IgE binding allergen epitopes generally comprise conformational and more hydrophobic patches present on the allergen. A significant proportion of the IgE is directed against the glycosylated B-cell epitopes [122]. This might be a consequence of the hundred-fold increased cellular uptake of glycosylated proteins and peptides by antigen-presenting cells compared to their non-glycoslyated counterparts and resulting in enhanced immune responses [123]. However, others suggest that glycosylation is not a common critical determinant of allergenicity as food allergens comprise both glycoproteins as well as non-glycosylated proteins [124].

An epitope is identified by its ability to bind antibodies and is suggested to consist of a recognizable sequence of 6-15 amino acids (covering a 11-13 nm distance) contributing to the binding between epitope and antibody molecule [125]. Two of these identical epitopes need to span a distance between 8 and $24 \mathrm{~nm}$, with a single amino acid being in the order of about $0.5 \mathrm{~nm}[126,127]$. A linear unit potentially leading to degranulation would then comprise a distance of $20-54 \mathrm{~nm}$ equaling $40-108$ amino acids (4.400 to $11.880 \mathrm{Da}$ ) [128]. In a $20 \mathrm{kDa}$ allergen this would represent $2-5$ units, while a $200 \mathrm{kDa}$ allergen would harbor 16-45 units. Indeed, most allergens have only one to five immunodominant epitopes. A 40 amino acid unit would be sufficient to induce IgE antibody formation and combine the potential to result in degranulation upon binding to IgE on sensitized mast cells.
\end{abstract}

Box 2. Immunochemical properties of IgE.

IgE molecules have a $12 \%$ carbohydrate content with oligosaccharides asparagine-linked at six places all in the first three of the four constant region domains, they have a limited segmental flexibility [129]. Therefore, $\operatorname{IgE}$ molecules are generally considered to be more rigid than IgG molecules putting emphasis on the importance of the inter-epitope distance resulting in proper IgE binding. This way a binding stoichiometry of two can be reached as closely as possible resulting in a high binding affinity of the allergen-specific IgE antibodies [130]. The relevance of IgE affinity is illustrated in studies showing that in allergic individuals, the peanut allergen Ara $\mathrm{h}$ 2-specific IgE affinity correlated with the severity of the allergic disease, but not with the level of specific $\operatorname{IgE}[129,131]$. In allergic individuals, IgE concentrations in the circulation may reach over 10 times the normal level $(\approx 150 \mathrm{ng} / \mathrm{mL}$ ), and who have an increased risk of developing allergies. However, the concentration of $\operatorname{IgE}$ in the serum of healthy individuals is $10^{4}$ times less than that of IgG.

These IgE antibodies have the capacity to bind to $\operatorname{IgE}$ Fc epsilon receptors with high affinity $\left(\mathrm{K}_{\mathrm{a}} \approx 10^{10} \mathrm{M}^{-1}\right)$. This exceptionally high affinity is mainly a reflection of the very slow dissociation rate with a half-life of about $20 \mathrm{~h}$ for circulating IgE. The residence time on mast cells in tissues is further extended to more than 14 days by restricted diffusion and rebinding to cell receptors [130].

Box 3. Advantage of functional tests on IgE binding assays in the diagnosis of food allergy.

Diagnosis of allergy is routinely based on binding of $\operatorname{IgE}$ antibodies to the relevant allergen in a serological test. Principally, this binding of one Fab fragment to a single epitope results in a positive reading representing immunogenicity. This mostly conformational monovalent binding interaction is not related to the capacity to induce an allergic response resulting into mediator release. For this reaction it is essential to achieve cross-linking of several specific IgE molecules bound to adjacent FcERI on mast cells and basophils (hence allergenicity). Principally, this elicitation phase requires a multivalent interaction between (mostly linear) allergen multi-epitopes and multiple Fab fragments on IgE antibodies. This allergen capacity can be analyzed ex vivo with blood-derived basophils or in vitro by using e.g., the rat basophilic leukemia (RBL)-HE3 cell line and is generally called allergenicity of the allergen. To analyze the basophil degranulation capacity sensitive assays are required as these cells comprise only $0-2 \%$ of leukocytes equaling $1-8 \times 10^{4}$ cells $/ \mathrm{mL}$ [130]. This different capacity of allergens should be taken into account when relating the functional activity of allergens to the clinical symptoms of allergy. High affinity Fce receptors are abundantly expressed (6000-600,000 receptors per cell) on mast cells in tissues and basophils in the blood. The number of FcERI per basophil varies between different donors (range 29,000-680,000) and is also related to the IgE concentration in the serum [131]. Upon IgE binding to their specific receptors, these cells are sensitized and therefore the individual is called sensitized. Minimally, 2000 of these FceRI bound specific IgE molecules need to be cross-linked by the relevant epitopes on the allergen in order to cause degranulation of the mast cell and/or basophil resulting in the release of the mediators and the development of acute complaints of a clinically observable allergic response. Therefore, functional assays such as histamine, $\beta$-hexosaminidase release assays or basophil activation tests should be included next to the conventional IgE binding tests to study the influence of Maillard reaction on allergenicity of proteins. 


\section{Conclusions}

In conclusion, the MR can alter immunoreactivity towards food proteins, and MR-modified proteins may enhance the immune response by selective interaction with APCs carrying receptors for AGE. In addition, it has become clear that the presentation of MR-modified allergens to T-cells may skew the subsequent T-cell differentiation into Th2 cells producing IL-4, IL-5 and IL-13, which are responsible for the initiation of $\operatorname{IgE}$ antibody production. Some studies also observed enhanced mediator release from basophils incubated with MR-modified proteins that may be resulting from: (a) the immunogenic potential of MRPs enhancing the sensitization; and/or (b) agglomeration leading to more efficient cross-linking and therefore mediator release. These findings reveal a need for better understanding of the influence of MR on both the sensitization phase as well as the development of the symptoms of the allergy. Understanding the mechanisms involved in immunoreactivity of AGEs would help to improve the diagnostics of food allergy as well as develop optimized conditions for food processing to control the rate of MR.

Acknowledgments: MT was partially supported by European Seventh Framework Program FP7-PEOPLE-2011-IEF, grant number PIEF-GA-2011-302295.

Author Contributions: MT, RJJvN and HFJS equally contributed to the writing process.

Conflicts of Interest: RJJvN is an employee of FrieslandCampina. HFJS and MT declare no conflict of interest.

\section{References}

1. Pereira, R.N.; Vicente, A.A. Environmental impact of novel thermal and non-thermal technologies in food processing. Food Res. Int. 2010, 43, 1936-1943. [CrossRef]

2. Ling, B.; Tang, J.; Kong, F.; Mitcham, E.J.; Wang, S. Kinetics of food quality changes during thermal processing: A review. Food Bioprocess Technol. 2015, 8, 343-358. [CrossRef]

3. Sevenich, R.; Bark, F.; Kleinstueck, E.; Crews, C.; Pye, C.; Hradecky, J.; Reineke, K.; Lavilla, M.; Martinez-de-Maranon, I.; Briand, J.C.; et al. The impact of high pressure thermal sterilization on the microbiological stability and formation of food processing contaminants in selected fish systems and baby food puree at pilot scale. Food Control 2015, 50, 539-547. [CrossRef]

4. Peng, P.; Song, H.; Zhang, T.; Addy, M.; Zhang, Y.; Cheng, Y.; Hatzenbeller, R.; Zhu, X.; Liu, S.; Liu, Y.; et al. Concentrated high intensity electric field (chief) system for non-thermal pasteurization of liquid foods: Modeling and simulation of fluid mechanics, electric analysis, and heat transfer. Comput. Chem. Eng. 2017, 97, 183-193. [CrossRef]

5. Halpin, R.M.; Duffy, L.; Cregenzán-Alberti, O.; Lyng, J.G.; Noci, F. The effect of non-thermal processing technologies on microbial inactivation: An investigation into sub-lethal injury of Escherichia coli and Pseudomonas fluorescens. Food Control 2014, 41, 106-115. [CrossRef]

6. Roberts, P.B. Food irradiation is safe: Half a century of studies. Radiat. Phys. Chem. 2014, 105, 78-82. [CrossRef]

7. Thirumdas, R.; Sarangapani, C.; Annapure, U.S. Cold plasma: A novel non-thermal technology for food processing. Food Biophys. 2015, 10, 1-11. [CrossRef]

8. Davis, P.J.; Williams, S.C. Protein modification by thermal processing. Allergy 1998, 53, 102-105. [CrossRef] [PubMed]

9. Tong, P.; Gao, J.; Chen, H.; Li, X.; Zhang, Y.; Jian, S.; Wichers, H.; Wu, Z.; Yang, A.; Liu, F. Effect of heat treatment on the potential allergenicity and conformational structure of egg allergen ovotransferrin. Food Chem. 2012, 131, 603-610. [CrossRef]

10. Murayama, K.; Tomida, M. Heat-induced secondary structure and conformation change of bovine serum albumin investigated by fourier transform infrared spectroscopy. Biochemistry 2004, 43, 11526-11532. [CrossRef] [PubMed]

11. Somoza, V.; Wenzel, E.; Weiss, C.; Clawin-Radecker, I.; Grubel, N.; Erbersdobler, H.F. Dose-dependent utilisation of casein-linked lysinoalanine, $\mathrm{N}$ (epsilon)-fructoselysine and $\mathrm{N}$ (epsilon)-carboxymethyllysine in rats. Mol. Nutr. Food Res. 2006, 50, 833-841. [CrossRef] [PubMed] 
12. Van Boekel, M.A. Kinetic aspects of the maillard reaction: A critical review. Mol. Nutr. Food Res. 2001, 45, 150-159.

13. Hellwig, M.; Henle, T. Baking, ageing, diabetes: A short history of the maillard reaction. Angew. Chem. Int. Ed. 2014, 53, 10316-10329. [CrossRef] [PubMed]

14. De Oliveira, F.C.; Coimbra, J.S.; de Oliveira, E.B.; Zuniga, A.D.; Rojas, E.E. Food protein-polysaccharide conjugates obtained via the maillard reaction: A review. Crit. Rev. Food Sci. Nutr. 2016, 56, 1108-1125. [CrossRef] [PubMed]

15. Henle, T. Protein-bound advanced glycation endproducts (ages) as bioactive amino acid derivatives in foods. Amino Acids 2005, 29, 313-322. [CrossRef] [PubMed]

16. Somoza, V. Five years of research on health risks and benefits of maillard reaction products: An update. Mol. Nutr. Food Res. 2005, 49, 663-672. [CrossRef] [PubMed]

17. Liu, J.; Ru, Q.; Ding, Y. Glycation a promising method for food protein modification: Physicochemical properties and structure, a review. Food Res. Int. 2012, 49, 170-183. [CrossRef]

18. Ames, J.M. Applications of the maillard reaction in the food industry. Food Chem. 1998, 62, 431-439. [CrossRef]

19. Teodorowicz, M.; Jansen, A.P.H.; Roovers, M.H.W.M.; Ruinemans-Koerts, J.; Wichers, H.J.; Savelkoul, H.F.J. Maillard-type neoallergens present in processed soy extract may cause an allergic reaction in soy allergic patients. Clin. Trans. Allergy 2015, 5, 21. [CrossRef]

20. Heilmann, M.; Wellner, A.; Gadermaier, G.; Ilchmann, A.; Briza, P.; Krause, M.; Nagai, R.; Burgdorf, S.; Scheurer, S.; Vieths, S.; et al. Ovalbumin modified with pyrraline, a maillard reaction product, shows enhanced T-cell immunogenicity. J. Biol. Chem. 2014, 289, 7919-7928. [CrossRef] [PubMed]

21. Moghaddam, A.E.; Hillson, W.R.; Noti, M.; Gartlan, K.H.; Johnson, S.; Thomas, B.; Artis, D.; Sattentau, Q.J. Dry roasting enhances peanut-induced allergic sensitization across mucosal and cutaneous routes in mice. J. Allergy Clin. Immunol. 2014, 134, 1453-1456. [CrossRef] [PubMed]

22. Iwan, M.; Vissers, Y.M.; Fiedorowicz, E.; Kostyra, H.; Kostyra, E.; Savelkoul, H.F.; Wichers, H.J. Impact of maillard reaction on immunoreactivity and allergenicity of the hazelnut allergen cor a 11. J.Agric. Food Chem. 2011, 59, 7163-7171. [CrossRef] [PubMed]

23. Lehmann, K.; Schweimer, K.; Reese, G.; Randow, S.; Suhr, M.; Becker, W.M.; Vieths, S.; Rosch, P. Structure and stability of $2 \mathrm{~s}$ albumin-type peanut allergens: Implications for the severity of peanut allergic reactions. Biochem. J. 2006, 395, 463-472. [CrossRef] [PubMed]

24. Suhr, M.; Wicklein, D.; Lepp, U.; Becker, W.M. Isolation and characterization of natural ara h 6: Evidence for a further peanut allergen with putative clinical relevance based on resistance to pepsin digestion and heat. Mol. Nutr. Food Res. 2004, 48, 390-399. [CrossRef] [PubMed]

25. Apostolovic, D.; Stanic-Vucinic, D.; de Jongh, H.H.; de Jong, G.A.; Mihailovic, J.; Radosavljevic, J.; Radibratovic, M.; Nordlee, J.A.; Baumert, J.L.; Milcic, M.; et al. Conformational stability of digestion-resistant peptides of peanut conglutins reveals the molecular basis of their allergenicity. Sci. Rep. 2016, 6, 29249. [CrossRef] [PubMed]

26. Bogh, K.L.; Madsen, C.B. Food allergens: Is there a correlation between stability to digestion and allergenicity? Crit. Rev. Food Sci. Nutr. 2016, 56, 1545-1567. [CrossRef] [PubMed]

27. Bannon, G.; Fu, T.J.; Kimber, I.; Hinton, D.M. Protein digestibility and relevance to allergenicity. Environ. Health Perspect. 2003, 111, 1122-1124. [CrossRef] [PubMed]

28. Peram, M.R.; Loveday, S.M.; Ye, A.; Singh, H. In vitro gastric digestion of heat-induced aggregates of $\beta$-lactoglobulin. J. Dairy Sci. 2013, 96, 63-74. [CrossRef] [PubMed]

29. Corzo-Martínez, M.; Soria, A.C.; Belloque, J.; Villamiel, M.; Moreno, F.J. Effect of glycation on the gastrointestinal digestibility and immunoreactivity of bovine $\beta$-lactoglobulin. Int. Dairy J. 2010, 20, 742-752. [CrossRef]

30. Corzo-Martinez, M.; Moreno, F.J.; Olano, A.; Villamiel, M. Role of pyridoxamine in the formation of the amadori/heyns compounds and aggregates during the glycation of beta-lactoglobulin with galactose and tagatose. J. Agric. Food Chem. 2010, 58, 500-506. [CrossRef] [PubMed]

31. Ahmad, S.; Shahab, U.; Baig, M.H.; Khan, M.S.; Khan, M.S.; Srivastava, A.K.; Saeed, M.; Moinuddin. Inhibitory effect of metformin and pyridoxamine in the formation of early, intermediate and advanced glycation end-products. PLoS ONE 2013, 8, e72128. [CrossRef] [PubMed] 
32. Dominika, Ś.; Arjan, N.; Karyn, R.P.; Henryk, K. The study on the impact of glycated pea proteins on human intestinal bacteria. Int. J. Food Microbiol. 2011, 145, 267-272. [CrossRef] [PubMed]

33. Teodorowicz, M.; Fiedorowicz, E.; Kostyra, H.; Wichers, H.; Kostyra, E. Effect of maillard reaction on biochemical properties of peanut $7 \mathrm{~s}$ globulin (ara h 1 ) and its interaction with a human colon cancer cell line (caco-2). Eur. J. Nutr. 2013, 52, 1927-1938. [CrossRef] [PubMed]

34. Luz Sanz, M.; Corzo-Martinez, M.; Rastall, R.A.; Olano, A.; Moreno, F.J. Characterization and in vitro digestibility of bovine beta-lactoglobulin glycated with galactooligosaccharides. J. Agric. Food Chem. 2007, 55, 7916-7925. [CrossRef] [PubMed]

35. Katayama, S.; Shima, J.; Saeki, H. Solubility improvement of shellfish muscle proteins by reaction with glucose and its soluble state in low-ionic-strength medium. J. Agric. Food Chem. 2002, 50, 4327-4332. [CrossRef] [PubMed]

36. Sato, R.; Sawabe, T.; Kishimura, H.; Hayashi, K.; Saeki, H. Preparation of neoglycoprotein from carp myofibrillar protein and alginate oligosaccharide: Improved solubility in low ionic strength medium. J. Agric. Food Chem. 2000, 48, 17-21. [CrossRef] [PubMed]

37. Yeboah, F.K.; Alli, I.; Yaylayan, V.A.; Yasuo, K.; Chowdhury, S.F.; Purisima, E.O. Effect of limited solid-state glycation on the conformation of lysozyme by esi-msms peptide mapping and molecular modeling. Bioconj. Chem. 2004, 15, 27-34. [CrossRef] [PubMed]

38. De Jongh, H.H.J.; Taylor, S.L.; Koppelman, S.J. Controlling the aggregation propensity and thereby digestibility of allergens by maillardation as illustrated for cod fish parvalbumin. J. Biosci. Bioeng. 2011, 111, 204-211. [CrossRef] [PubMed]

39. Liu, F.; Teodorowicz, M.; Wichers, H.J.; van Boekel, M.A.; Hettinga, K.A. Generation of soluble advanced glycation end products receptor (srage)-binding ligands during extensive heat treatment of whey protein/lactose mixtures is dependent on glycation and aggregation. J Agric. Food Chem. 2016, 64, 6477-6486. [CrossRef] [PubMed]

40. Seiquer, I.; Diaz-Alguacil, J.; Delgado-Andrade, C.; Lopez-Frias, M.; Munoz Hoyos, A.; Galdo, G.; Navarro, M.P. Diets rich in maillard reaction products affect protein digestibility in adolescent males aged 11-14 y. Am. J. Clin. Nutr. 2006, 83, 1082-1088. [PubMed]

41. Hellwig, M.; Bunzel, D.; Huch, M.; Franz, C.M.; Kulling, S.E.; Henle, T. Stability of individual maillard reaction products in the presence of the human colonic microbiota. J. Agric. Food Chem. 2015, 63, 6723-6730. [CrossRef] [PubMed]

42. Hellwig, M.; Henle, T. Release of pyrraline in absorbable peptides during simulated digestion of casein glycated by 3-deoxyglucosone. Eur. Food Res. Technol. 2013, 237, 47-55. [CrossRef]

43. Koschinsky, T.; He, C.-J.; Mitsuhashi, T.; Bucala, R.; Liu, C.; Buenting, C.; Heitmann, K.; Vlassara, H. Orally absorbed reactive glycation products (glycotoxins): An environmental risk factor in diabetic nephropathy. Proc. Natl. Acad. Sci. USA 1997, 94, 6474-6479. [CrossRef] [PubMed]

44. Uribarri, J.; Cai, W.; Sandu, O.; Peppa, M.; Goldberg, T.; Vlassara, H. Diet-derived advanced glycation end products are major contributors to the body's age pool and induce inflammation in healthy subjects. Ann. N. Y. Acad. Sci. 2005, 1043, 461-466. [CrossRef] [PubMed]

45. Delgado-Andrade, C.; Tessier, F.J.; Niquet-Leridon, C.; Seiquer, I.; Pilar Navarro, M. Study of the urinary and faecal excretion of nepsilon-carboxymethyllysine in young human volunteers. Amino Acids 2012, 43, 595-602. [CrossRef] [PubMed]

46. Foerster, A.; Henle, T. Glycation in food and metabolic transit of dietary ages (advanced glycation end-products): Studies on the urinary excretion of pyrraline. Biochem. Soc. Trans. 2003, 31, 1383-1385. [CrossRef] [PubMed]

47. Forster, A.; Kuhne, Y.; Henle, T. Studies on absorption and elimination of dietary maillard reaction products. Ann. N. Y. Acad. Sci. 2005, 1043, 474-481. [CrossRef] [PubMed]

48. Semba, R.D.; Ang, A.; Talegawkar, S.; Crasto, C.; Dalal, M.; Jardack, P.; Traber, M.G.; Ferrucci, L.; Arab, L. Dietary intake associated with serum versus urinary carboxymethyl-lysine, a major advanced glycation end product, in adults: The energetics study. Eur. J. Clin. Nutr. 2012, 66, 3-9. [CrossRef] [PubMed]

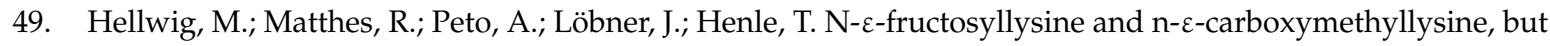
not lysinoalanine, are available for absorption after simulated gastrointestinal digestion. Amino Acids 2014, 46, 289-299. [CrossRef] [PubMed] 
50. Ames, J.M. Evidence against dietary advanced glycation endproducts being a risk to human health. Mol. Nutr. Food Res. 2007, 51, 1085-1090. [CrossRef] [PubMed]

51. Roth-Walter, F.; Berin, M.C.; Arnaboldi, P.; Escalante, C.R.; Dahan, S.; Rauch, J.; Jensen-Jarolim, E.; Mayer, L. Pasteurization of milk proteins promotes allergic sensitization by enhancing uptake through peyer's patches. Allergy 2008, 63, 882-890. [CrossRef] [PubMed]

52. Stojadinovic, M.; Pieters, R.; Smit, J.; Velickovic, T.C. Cross-linking of beta-lactoglobulin enhances allergic sensitization through changes in cellular uptake and processing. Toxicol. Sci. 2014, 140, 224-235. [CrossRef] [PubMed]

53. Tuohy, K.M.; Hinton, D.J.; Davies, S.J.; Crabbe, M.J.; Gibson, G.R.; Ames, J.M. Metabolism of maillard reaction products by the human gut microbiota-implications for health. Mol. Nutr. Food Res. 2006, 50, 847-857. [CrossRef] [PubMed]

54. Helou, C.; Marier, D.; Jacolot, P.; Abdennebi-Najar, L.; Niquet-Leridon, C.; Tessier, F.J.; Gadonna-Widehem, P. Microorganisms and maillard reaction products: A review of the literature and recent findings. Amino Acids 2014, 46, 267-277. [CrossRef] [PubMed]

55. Seiquer, I.; Rubio, L.A.; Peinado, M.J.; Delgado-Andrade, C.; Navarro, M.P. Maillard reaction products modulate gut microbiota composition in adolescents. Mol. Nutr. Food Res. 2014, 58, 1552-1560. [CrossRef] [PubMed]

56. Teodorowicz, M.; Świątecka, D.; Savelkoul, H.; Wichers, H.; Kostyra, E.C. Hydrolysates of glycated and heat-treated peanut 7s globulin (ara h 1) modulate human gut microbial proliferation, survival and adhesion. J. Appl. Microbiol. 2014, 116, 424-434. [CrossRef] [PubMed]

57. Yan, S.F.; Ramasamy, R.; Schmidt, A.M. Mechanisms of disease: Advanced glycation end-products and their receptor in inflammation and diabetes complications. Nat. Rev. Endocrinol. 2008, 4, 285-293. [CrossRef] [PubMed]

58. Davis, K.E.; Prasad, C.; Vijayagopal, P.; Juma, S.; Imrhan, V. Advanced glycation end products, inflammation, and chronic metabolic diseases: Links in a chain? Crit. Rev. Food Sci. Nutr. 2016, 56, 989-998. [CrossRef] [PubMed]

59. Wu, L.C.; Zarrin, A.A. The production and regulation of ige by the immune system. Nat. Rev. Immunol. 2014, 14, 247-259. [CrossRef] [PubMed]

60. Guilliams, M.; Bruhns, P.; Saeys, Y.; Hammad, H.; Lambrecht, B.N. The function of Fc[gamma] receptors in dendritic cells and macrophages. Nat. Rev. Immunol. 2014, 14, 94-108. [CrossRef] [PubMed]

61. Bertheloot, D.; Naumovski, A.L.; Langhoff, P.; Horvath, G.L.; Jin, T.; Xiao, T.S.; Garbi, N.; Agrawal, S.; Kolbeck, R.; Latz, E. Rage enhances tlr responses through binding and internalization of rna. J. Immunol. 2016, 197, 4118-4126. [CrossRef] [PubMed]

62. Schmidt, A.M.; Vianna, M.; Gerlach, M.; Brett, J.; Ryan, J.; Kao, J.; Esposito, C.; Hegarty, H.; Hurley, W.; Clauss, M.; et al. Isolation and characterization of two binding proteins for advanced glycosylation end products from bovine lung which are present on the endothelial cell surface. J. Biol. Chem. 1992, 267, 14987-14997. [PubMed]

63. Maldonado, S.; Dai, J.; Singh, S.; Mwangi, D.; Rivera, A.; Fitzgerald-Bocarsly, P. Human pdcs express the c-type lectin receptor dectin-1 and uptake and kill Aspergillus fumigatus spores in vitro (mpf4p.734). J. Immunol. 2015, 194, 136.10.

64. Zhu, L.L.; Zhao, X.Q.; Jiang, C.; You, Y.; Chen, X.P.; Jiang, Y.Y.; Jia, X.M.; Lin, X. C-type lectin receptors dectin-3 and dectin-2 form a heterodimeric pattern-recognition receptor for host defense against fungal infection. Immunity 2013, 39, 324-334. [CrossRef] [PubMed]

65. Sprokholt, J.K.; Overmars, R.J.; Geijtenbeek, T.B.H. Dc-sign in infection and immunity. In C-type Lectin Receptors in Immunity; Yamasaki, S., Ed.; Springer: Tokyo, Japan, 2016; pp. 129-150.

66. Lakshminarayan, R.; Wunder, C.; Becken, U.; Howes, M.T.; Benzing, C.; Arumugam, S.; Sales, S.; Ariotti, N.; Chambon, V.; Lamaze, C.; et al. Galectin-3 drives glycosphingolipid-dependent biogenesis of clathrin-independent carriers. Nat. Cell Biol. 2014, 16, 592-603. [CrossRef] [PubMed]

67. Azad, A.K.; Rajaram, M.V.S.; Schlesinger, L.S. Exploitation of the macrophage mannose receptor (cd206) in infectious disease diagnostics and therapeutics. J. Cytol. Mol. Biol. 2014, 1, 1000003. [PubMed]

68. Gosselin, E.J.; Wardwell, K.; Gosselin, D.R.; Alter, N.; Fisher, J.L.; Guyre, P.M. Enhanced antigen presentation using human fc gamma receptor (monocyte/macrophage)-specific immunogens. J. Immunol. 1992, 149, 3477-3481. [PubMed] 
69. Van der Heijden, F.L.; Joost van Neerven, R.J.; van Katwijk, M.; Bos, J.D.; Kapsenberg, M.L. Serum-ige-facilitated allergen presentation in atopic disease. J. Immunol. 1993, 150, 3643. [PubMed]

70. Buttari, B.; Profumo, E.; Capozzi, A.; Facchiano, F.; Saso, L.; Sorice, M.; Rigano, R. Advanced glycation end products of human beta(2) glycoprotein i modulate the maturation and function of dcs. Blood 2011, 117, 6152-6161. [CrossRef] [PubMed]

71. Ge, J.; Jia, Q.; Liang, C.; Luo, Y.; Huang, D.; Sun, A.; Wang, K.; Zou, Y.; Chen, H. Advanced glycosylation end products might promote atherosclerosis through inducing the immune maturation of dendritic cells. Arterioscler. Thromb. Vasc. Biol. 2005, 25, 2157-2163. [CrossRef] [PubMed]

72. Ilchmann, A.; Burgdorf, S.; Scheurer, S.; Waibler, Z.; Nagai, R.; Wellner, A.; Yamamoto, Y.; Yamamoto, H.; Henle, T.; Kurts, C.; et al. Glycation of a food allergen by the maillard reaction enhances its t-cell immunogenicity: Role of macrophage scavenger receptor class a type i and ii. J. Allergy Clin. Immunol. 2010, 125, 175-183.e111. [CrossRef] [PubMed]

73. Ott, C.; Jacobs, K.; Haucke, E.; Navarrete Santos, A.; Grune, T.; Simm, A. Role of advanced glycation end products in cellular signaling. Redox Biol. 2014, 2, 411-429. [CrossRef] [PubMed]

74. Li, Y.M.; Mitsuhashi, T.; Wojciechowicz, D.; Shimizu, N.; Li, J.; Stitt, A.; He, C.; Banerjee, D.; Vlassara, H. Molecular identity and cellular distribution of advanced glycation endproduct receptors: Relationship of p60 to ost-48 and p90 to 80k-h membrane proteins. Proc. Natl. Acad. Sci. USA 1996, 93, 11047-11052. [CrossRef] [PubMed]

75. Vlassara, H.; Li, Y.M.; Imani, F.; Wojciechowicz, D.; Yang, Z.; Liu, F.T.; Cerami, A. Identification of galectin-3 as a high-affinity binding protein for advanced glycation end products (age): A new member of the age-receptor complex. Mol. Med. 1995, 1, 634-646. [PubMed]

76. Ohgami, N.; Nagai, R.; Ikemoto, M.; Arai, H.; Kuniyasu, A.; Horiuchi, S.; Nakayama, H. Cd36, a member of the class b scavenger receptor family, as a receptor for advanced glycation end products. J. Biol. Chem. 2001, 276, 3195-3202. [CrossRef] [PubMed]

77. Chatzigeorgiou, A.; Kandaraki, E.; Piperi, C.; Livadas, S.; Papavassiliou, A.G.; Koutsilieris, M.; Papalois, A.; Diamanti-Kandarakis, E. Dietary glycotoxins affect scavenger receptor expression and the hormonal profile of female rats. J. Endocrinol. 2013, 218, 331-337. [CrossRef] [PubMed]

78. Araki, N.; Higashi, T.; Mori, T.; Shibayama, R.; Kawabe, Y.; Kodama, T.; Takahashi, K.; Shichiri, M.; Horiuchi, S. Macrophage scavenger receptor mediates the endocytic uptake and degradation of advanced glycation end products of the maillard reaction. Eur. J. Biochem. 1995, 230, 408-415. [CrossRef] [PubMed]

79. Chakraborty, P.; Ghosh, D.; Basu, M.K. Modulation of macrophage mannose receptor affects the uptake of virulent and avirulent leishmania donovani promastigotes. J. Parasitol. 2001, 87, 1023-1027. [CrossRef]

80. Hilmenyuk, T.; Bellinghausen, I.; Heydenreich, B.; Ilchmann, A.; Toda, M.; Grabbe, S.; Saloga, J. Effects of glycation of the model food allergen ovalbumin on antigen uptake and presentation by human dendritic cells. Immunology 2010, 129, 437-445. [CrossRef] [PubMed]

81. Royer, P.J.; Emara, M.; Yang, C.; Al-Ghouleh, A.; Tighe, P.; Jones, N.; Sewell, H.F.; Shakib, F.; Martinez-Pomares, L.; Ghaemmaghami, A.M. The mannose receptor mediates the uptake of diverse native allergens by dendritic cells and determines allergen-induced t cell polarization through modulation of ido activity. J. Immunol. 2010, 185, 1522-1531. [CrossRef] [PubMed]

82. Mueller, G.A.; Maleki, S.J.; Johnson, K.; Hurlburt, B.K.; Cheng, H.; Ruan, S.; Nesbit, J.B.; Pomés, A.; Edwards, L.L.; Schorzman, A.; et al. Identification of maillard reaction products on peanut allergens that influence binding to the receptor for advanced glycation end products. Allergy 2013, 68, 1546-1554. [CrossRef] [PubMed]

83. Liu, F.; Teodorowicz, M.; van Boekel, M.A.; Wichers, H.J.; Hettinga, K.A. The decrease in the igg-binding capacity of intensively dry heated whey proteins is associated with intense maillard reaction, structural changes of the proteins and formation of rage-ligands. Food Funct. 2016, 7, 239-249. [CrossRef] [PubMed]

84. Holik, A.K.; Rohm, B.; Somoza, M.M.; Somoza, V. N(epsilon)-carboxymethyllysine (cml), a maillard reaction product, stimulates serotonin release and activates the receptor for advanced glycation end products (rage) in sh-sy5y cells. Food Funct. 2013, 4, 1111-1120. [CrossRef] [PubMed]

85. Neeper, M.; Schmidt, A.M.; Brett, J.; Yan, S.D.; Wang, F.; Pan, Y.C.; Elliston, K.; Stern, D.; Shaw, A. Cloning and expression of a cell surface receptor for advanced glycosylation end products of proteins. J. Biol. Chem. 1992, 267, 14998-15004. [PubMed] 
86. Bastos, D.H.M.; Gugliucci, A. Contemporary and controversial aspects of the maillard reaction products. Curr. Opin. Food Sci. 2015, 1, 13-20. [CrossRef]

87. Devangelio, E.; Santilli, F.; Formoso, G.; Ferroni, P.; Bucciarelli, L.; Michetti, N.; Clissa, C.; Ciabattoni, G.; Consoli, A.; Davì, G. Soluble rage in type 2 diabetes: Association with oxidative stress. Free. Radic. Biol. Med. 2007, 43, 511-518. [CrossRef] [PubMed]

88. Raucci, A.; Cugusi, S.; Antonelli, A.; Barabino, S.M.; Monti, L.; Bierhaus, A.; Reiss, K.; Saftig, P.; Bianchi, M.E. A soluble form of the receptor for advanced glycation endproducts (rage) is produced by proteolytic cleavage of the membrane-bound form by the sheddase a disintegrin and metalloprotease 10 (adam10). FASEB J. 2008, 22, 3716-3727. [CrossRef] [PubMed]

89. Yamagishi, S.-I.; Nakamura, N.; Suematsu, M.; Kaseda, K.; Matsui, T. Advanced glycation end products: A molecular target for vascular complications in diabetes. Mol. Med. 2015, 21, S32-S40. [CrossRef] [PubMed]

90. Yamagishi, S.; Nakamura, K.; Matsui, T.; Ueda, S.; Fukami, K.; Okuda, S. Agents that block advanced glycation end product (age)-rage (receptor for ages)-oxidative stress system: A novel therapeutic strategy for diabetic vascular complications. Exp. Opin. Investig. Drugs 2008, 17, 983-996. [CrossRef] [PubMed]

91. Gugliucci, A.; Menini, T. The axis age-rage-soluble rage and oxidative stress in chronic kidney disease. In Oxidative Stress and Inflammation in Non-Communicable Diseases-Molecular Mechanisms and Perspectives in Therapeutics; Camps, J., Ed.; Springer International Publishing: Cham, Germany, 2014; pp. 191-208.

92. Reddy, V.P.; Beyaz, A. Inhibitors of the maillard reaction and age breakers as therapeutics for multiple diseases. Drug Discov. Today 2006, 11, 646-654. [CrossRef] [PubMed]

93. Maillard-Lefebvre, H.; Boulanger, E.; Daroux, M.; Gaxatte, C.; Hudson, B.I.; Lambert, M. Soluble receptor for advanced glycation end products: A new biomarker in diagnosis and prognosis of chronic inflammatory diseases. Rheumatology 2009, 48, 1190-1196. [CrossRef] [PubMed]

94. Zill, H.; Bek, S.; Hofmann, T.; Huber, J.; Frank, O.; Lindenmeier, M.; Weigle, B.; Erbersdobler, H.F.; Scheidler, S.; Busch, A.E.; et al. Rage-mediated mapk activation by food-derived age and non-age products. Biochem. Biophys. Res. Commun. 2003, 300, 311-315. [CrossRef]

95. Hou, F.F.; Ren, H.; Owen, W.F., Jr.; Guo, Z.J.; Chen, P.Y.; Schmidt, A.M.; Miyata, T.; Zhang, X. Enhanced expression of receptor for advanced glycation end products in chronic kidney disease. J. Am. Soc. Nephrol. JASN 2004, 15, 1889-1896. [CrossRef] [PubMed]

96. Kislinger, T.; Fu, C.; Huber, B.; Qu, W.; Taguchi, A.; Du Yan, S.; Hofmann, M.; Yan, S.F.; Pischetsrieder, M.; Stern, D.; et al. N(epsilon)-(carboxymethyl)lysine adducts of proteins are ligands for receptor for advanced glycation end products that activate cell signaling pathways and modulate gene expression. J. Biol. Chem. 1999, 274, 31740-31749. [CrossRef] [PubMed]

97. Buetler, T.M.; Leclerc, E.; Baumeyer, A.; Latado, H.; Newell, J.; Adolfsson, O.; Parisod, V.; Richoz, J.; Maurer, S.; Foata, F.; et al. Ne-carboxymethyllysine-modified proteins are unable to bind to rage and activate an inflammatory response. Mol. Nutr. Food Res. 2008, 52, 370-378. [CrossRef] [PubMed]

98. Buetler, T.M.; Latado, H.; Leclerc, E.; Weigle, B.; Baumeyer, A.; Heizmann, C.W.; Scholz, G. Glycolaldehyde-modified $\beta$-lactoglobulin ages are unable to stimulate inflammatory signaling pathways in rage-expressing human cell lines. Mol. Nutr. Food Res. 2011, 55, 291-299. [CrossRef] [PubMed]

99. Muscat, S.; Pelka, J.; Hegele, J.; Weigle, B.; Münch, G.; Pischetsrieder, M. Coffee and maillard products activate nf-kb in macrophages via $\mathrm{H}_{2} \mathrm{O}_{2}$ production. Mol. Nutr. Food Res. 2007, 51, 525-535. [CrossRef] [PubMed]

100. Cellmer, T.; Bratko, D.; Prausnitz, J.M.; Blanch, H.W. Protein aggregation in silico. Trends Biotechnol. 2007, 25, 254-261. [CrossRef] [PubMed]

101. Lee, J.-J.; Wang, P.-W.; Yang, I.H.; Wu, C.-L.; Chuang, J.-H. Amyloid-beta mediates the receptor of advanced glycation end product-induced pro-inflammatory response via toll-like receptor 4 signaling pathway in retinal ganglion cell line rgc-5. Int. J. Biochem. Cell Biol. 2015, 64, 1-10. [CrossRef] [PubMed]

102. Sadigh-Eteghad, S.; Sabermarouf, B.; Majdi, A.; Talebi, M.; Farhoudi, M.; Mahmoudi, J. Amyloid-beta: A crucial factor in Alzheimer's disease. Med. Princ. Pract. 2015, 24, 1-10. [CrossRef] [PubMed]

103. Cianferoni, A.; Spergel, J.M. Food allergy: Review, classification and diagnosis. Allergol. Int. 2009, 58, 457-466. [CrossRef] [PubMed]

104. Rahaman, T.; Vasiljevic, T.; Ramchandran, L. Conformational changes of beta-lactoglobulin induced by shear, heat, and ph-effects on antigenicity. J. Dairy Sci. 2015, 98, 4255-4265. [CrossRef] [PubMed] 
105. Scheurer, S.; Lauer, I.; Foetisch, K.; San Miguel Moncin, M.; Retzek, M.; Hartz, C.; Enrique, E.; Lidholm, J.; Cistero-Bahima, A.; Vieths, S. Strong allergenicity of pru av 3, the lipid transfer protein from cherry, is related to high stability against thermal processing and digestion. J. Allergy Clin. Immunol. 2004, 114, 900-907. [CrossRef] [PubMed]

106. Gruber, P.; Vieths, S.; Wangorsch, A.; Nerkamp, J.; Hofmann, T. Maillard reaction and enzymatic browning Aaffect the allergenicity of pru av 1, the major allergen from cherry (Prunus avium). J. Agric. Food Chem. 2004, 52, 4002-4007. [CrossRef] [PubMed]

107. Jimenez-Saiz, R.; Belloque, J.; Molina, E.; Lopez-Fandino, R. Human immunoglobulin e (ige) binding to heated and glycated ovalbumin and ovomucoid before and after in vitro digestion. J. Agric. Food Chem. 2011, 59, 10044-10051. [CrossRef] [PubMed]

108. Taheri-Kafrani, A.; Gaudin, J.C.; Rabesona, H.; Nioi, C.; Agarwal, D.; Drouet, M.; Chobert, J.M.; Bordbar, A.K.; Haertle, T. Effects of heating and glycation of beta-lactoglobulin on its recognition by ige of sera from cow milk allergy patients. J. Agric. Food Chem. 2009, 57, 4974-4982. [CrossRef] [PubMed]

109. Vissers, Y.M.; Blanc, F.; Skov, P.S.; Johnson, P.E.; Rigby, N.M.; Przybylski-Nicaise, L.; Bernard, H.; Wal, J.-M.; Ballmer-Weber, B.; Zuidmeer-Jongejan, L.; et al. Effect of heating and glycation on the allergenicity of $2 \mathrm{~s}$ albumins (ara h 2/6) from peanut. PLoS ONE 2011, 6, e23998. [CrossRef] [PubMed]

110. Vissers, Y.M.; Iwan, M.; Adel-Patient, K.; Stahl Skov, P.; Rigby, N.M.; Johnson, P.E.; Mandrup Muller, P.; Przybylski-Nicaise, L.; Schaap, M.; Ruinemans-Koerts, J.; et al. Effect of roasting on the allergenicity of major peanut allergens ara h 1 and ara h 2/6: The necessity of degranulation assays. Clin. Exp. Allergy J. Br. Soc. Allergy Clin. Immunol. 2011, 41, 1631-1642. [CrossRef] [PubMed]

111. Cucu, T.; De Meulenaer, B.; Bridts, C.; Devreese, B.; Ebo, D. Impact of thermal processing and the maillard reaction on the basophil activation of hazelnut allergic patients. Food Chem. Toxicol. Int. J. Publ. Br. Ind. Biol. Res. Assoc. 2012, 50, 1722-1728. [CrossRef] [PubMed]

112. Maleki, S.J.; Chung, S.-Y.; Champagne, E.T.; Raufman, J.-P. The effects of roasting on the allergenic properties of peanut proteins. J. Allergy Clin. Immunol. 2000, 106, 763-768. [CrossRef] [PubMed]

113. Gruber, P.; Becker, W.M.; Hofmann, T. Influence of the maillard reaction on the allergenicity of rara $\mathrm{h} 2$, a recombinant major allergen from peanut (Arachis hypogaea), its major epitopes, and peanut agglutinin. J. Agric. Food Chem. 2005, 53, 2289-2296. [CrossRef] [PubMed]

114. Nakamura, A.; Watanabe, K.; Ojima, T.; Ahn, D.H.; Saeki, H. Effect of maillard reaction on allergenicity of scallop tropomyosin. J. Agric. Food Chem. 2005, 53, 7559-7564. [CrossRef] [PubMed]

115. Toda, M.; Heilmann, M.; Ilchmann, A.; Vieths, S. The maillard reaction and food allergies: Is there a link? Clin. Chem. Lab. Med. CCLM/FESCC 2014, 52, 61-67. [CrossRef] [PubMed]

116. Gupta, R.K.; Gupta, K.; Sharma, A.; Das, M.; Ansari, I.A.; Dwivedi, P.D. Maillard reaction in food allergy: Pros and cons. Crit. Rev. Food Sci. Nutr. 2016, 1-19. [CrossRef] [PubMed]

117. Vojdani, A. Detection of ige, igg, iga and igm antibodies against raw and processed food antigens. Nutr. Metab. 2009, 6, 22. [CrossRef] [PubMed]

118. Sampson, H.A.; Ho, D.G. Relationship between food-specific ige concentrations and the risk of positive food challenges in children and adolescents. J. Allergy Clin. Immunol. 1997, 100, 444-451. [CrossRef]

119. Huby, R.D.; Dearman, R.J.; Kimber, I. Why are some proteins allergens? Toxicol. Sci. 2000, 55, $235-246$. [CrossRef] [PubMed]

120. Aalberse, R.C. Structural biology of allergens. J. Allergy Clin. Immunol. 2000, 106, 228-238. [CrossRef] [PubMed]

121. Bredehorst, R.; David, K. What establishes a protein as an allergen? J. Chromatogr. B Biomed. Sci. Appl. 2001, 756, 33-40. [CrossRef]

122. James, J.A.; Harley, J.B. B-cell epitope spreading in autoimmunity. Immunol. Rev. 1998, 164, $185-200$. [CrossRef] [PubMed]

123. Dall'Antonia, F.; Pavkov-Keller, T.; Zangger, K.; Keller, W. Structure of allergens and structure based epitope predictions. Methods 2014, 66, 3-21. [CrossRef] [PubMed]

124. Pomes, A.; Chruszcz, M.; Gustchina, A.; Wlodawer, A. Interfaces between allergen structure and diagnosis: Know your epitopes. Curr. Allergy Asthma Rep. 2015, 15, 506. [CrossRef] [PubMed]

125. Handlogten, M.W.; Kiziltepe, T.; Serezani, A.P.; Kaplan, M.H.; Bilgicer, B. Inhibition of weak-affinity epitope-ige interactions prevents mast cell degranulation. Nat. Chem. Biol. 2013, 9, 789-795. [CrossRef] [PubMed] 
126. Baenziger, J.; Kornfeld, S.; Kochwa, S. Structure of the carbohydrate units of ige immunoglobulin. I. Over-all composition, glycopeptide isolation, and structure of the high mannose oligosaccharide unit. J. Biol. Chem. 1974, 249, 1889-1896. [PubMed]

127. Gould, H.J.; Sutton, B.J. Ige in allergy and asthma today. Nat. Rev. Immunol. 2008, 8, 205-217. [CrossRef] [PubMed]

128. El-Khouly, F.; Lewis, S.A.; Pons, L.; Burks, A.W.; Hourihane, J.O.B. Igg and ige avidity characteristics of peanut allergic individuals. Pediatr. Allergy Immunol. 2007, 18, 607-613. [CrossRef] [PubMed]

129. Wang, J.; Lin, J.; Bardina, L.; Goldis, M.; Nowak-Wegrzyn, A.; Shreffler, W.G.; Sampson, H.A. Correlation of ige/igg4 milk epitopes and affinity of milk-specific ige antibodies with different phenotypes of clinical milk allergy. J. Allergy Clin. Immunol. 2010, 125, 695-702.e6. [CrossRef] [PubMed]

130. Gould, H.J.; Sutton, B.J.; Beavil, A.J.; Beavil, R.L.; McCloskey, N.; Coker, H.A.; Fear, D.; Smurthwaite, L. The biology of ige and the basis of allergic disease. Ann. Rev. Immunol. 2003, 21, 579-628. [CrossRef] [PubMed]

131. Knol, E.F. Requirements for effective ige cross-linking on mast cells and basophils. Mol. Nutr. Food Res. 2006, 50, 620-624. [CrossRef] [PubMed]

(C) 2017 by the authors. Licensee MDPI, Basel, Switzerland. This article is an open access article distributed under the terms and conditions of the Creative Commons Attribution (CC BY) license (http:/ / creativecommons.org/licenses/by/4.0/). 